\title{
Ethnologies
}

\section{Performing Tradition and Ethnicity at the Newfoundland St. Andrew's Society Burns Supper}

\section{Joy Fraser}

Volume 30, numéro 2, 2008

Hommage à Peter Narváez

In Honour of Peter Narváez

URI : https://id.erudit.org/iderudit/019951ar

DOI : https://doi.org/10.7202/019951ar

Aller au sommaire du numéro

Éditeur(s)

Association Canadienne d'Ethnologie et de Folklore

ISSN

1481-5974 (imprimé)

1708-0401 (numérique)

Découvrir la revue

Citer cet article

Fraser, J. (2008). Performing Tradition and Ethnicity at the Newfoundland St. Andrew's Society Burns Supper. Ethnologies, 30(2), 181-200.

https://doi.org/10.7202/019951ar
Résumé de l'article

Cet article explore les conceptualisations contradictoires de la tradition et de l'ethnicité, telles qu'elles sont représentées lors de la célébration annuelle à St John's (Terre-Neuve) de l'identité écossaise : le dîner Burns de la Newfoundland St Andrew's Society. En premier, on discute de l'importance que revêtent les notions de maintien de la tradition et de la célébration de l'ethnicité pour les organisateurs de l'événement ainsi que pour les participants. L'article s'attache ensuite en détail à deux représentations de Christopher et Michael Pickard, poètes et artistes locaux qui furent les invités d'honneur de l'événement de janvier 2007. Ces représentations encodent des comportements sensiblement différents allant à l'encontre de la tradition et de l'ethnicité comparativement à ceux qui sont à la base du Burns Supper dans son ensemble. L'analyse des représentations des frères Pickard permet d'examiner les tensions générées quand ces deux perspectives contradictoires se confrontent dans le contexte d'un événement public comme le Burns Supper. Cela permet également d'élucider des questions plus vastes liées à la tradition et à l'ethnicité mises en jeu lors du déroulement de l'événement.
Ce document est protégé par la loi sur le droit d'auteur. L'utilisation des services d’Érudit (y compris la reproduction) est assujettie à sa politique d'utilisation que vous pouvez consulter en ligne.

https://apropos.erudit.org/fr/usagers/politique-dutilisation/ 


\title{
Performing Tradition and Ethnicity at the Newfoundland St. Andrew's Society Burns SUPPER
}

\author{
Joy Fraser \\ $M$ emorial $U$ niversity of $N$ ewfoundland
}

The N ewfoundland St. A ndrew's Society Burns Supper, which takes place each January in the provincial capital of St. John's, is one of hundreds of similar events held annually since the early $1800 \mathrm{~s}$, in Scotland and around the world. Their common purpose is to celebrate the anniversary of the birth of Scottish poet Robert Burns and "to honour the Scotland he represents" (Brown 1984: 138). ${ }^{1}$ This calendar custom's core elements include a meal of haggis and other Scottish fare; a series of speeches, toasts and recitations of Burns's poetry; and performances of Scottish music and dance. January 2007 marked the 170th anniversary of the Burns Supper tradition in St. John's, where the event first took place in $1837 .^{2}$ The Supper was held as usual in the ballroom of the local Royal Canadian Legion branch, with around 160 people in attendance (M owbray 2007c).

1. For a history and discussion of the Burns Supper tradition, see Brown 1984: 117-139. For scholarship on the "cult" or "myth" of Burns and his construction as a symbol of Scottish national identity, see, for example, Brown 1984; Davis 1998; Finlay 1997a, 1997b; H ammond 1993; Kirkwood 2000; M cG uirk 1987, 1997; Roe 1997; Strauss 1989; and Tyrrell 2005.

2. For a brief history of the N ewfoundland St. A ndrew's Society, including the Burns Supper, see M owbray 2002; see also N ewfoundland St. A ndrew's Society 2007. 
The participants' conceptualisations of tradition and ethnicity fundamentally inform and shape the celebration of the Burns Supper in St. John's. R esponses to an e-mail questionnaire I distributed to audience members at the 2007 Supper cite "carrying on the tradition" - or simply "tradition" - as a key motivating factor in the continuation of the event, thereby reifying and ascribing an inherent value to the concept. ${ }^{3}$ For example, one respondent writes that the purpose of the Burns Supper is "to continue a Scottish tradition from our cultural history," while another states more generally that "it is al ways important to carry on traditions, too many are lost." A third audience member observes that "having an annual Burns Supper is a tradition which has taken place for over 200 years and I think as Scots we are proud to organize this." Similarly, in an interview, the St. A ndrew's Society president, G raham M owbray, comments that "we're keeping a tradition alive, and I think that we all get a sense of value out of that... You [can't] just throw traditions away" (2007c). The notion of maintaining tradition thus assumes the status of a moral responsibility or obligation, with G raham adding that "this thing started in 1837, and, boy, I don't want to be the one who locks the door, and walks away from it" (M owbray 2007c).

Those involved in the St. John's Burns Supper also emphasise its role in "celebrating" and "promoting" Scottish "culture," "heritage," and "identity" in the city. Some questionnaire respondents comment that the event provides "an annual opportunity to bring expatriate Scots together," to "express a sense of community and collective identity" and to "[celebrate] a cultural strand in our community." 0 thers mention that it is "a way for those from Scotland to keep the culture...alive" and to "retain the identity of the country of their birth," thereby linking the notion of celebrating ethnicity to that of maintaining tradition. There is also a strong sense among the event's organisers and participants that "the Scottish contribution to $\mathrm{N}$ ewfoundland society is not adequately recognized," especially when compared with those of the larger and more visible sections of the population claiming I rish and English descent (Trew 2005). ${ }^{4}$ Viewed in this light, as organising committee member

3. A II uncited quotations below are taken from the responses to this audience questionnaire.

4. In the 2001 C ensus of $C$ anada, 13,520 (7.9\%) of the total of 171,105 responses for the St. John's M etropolitan A rea reported Scottish ethnic origins (figures include both single and multiple responses, where respondents reported more than one ethnic origin). Scottish was the fourth largest ethnic origin reported 
Jennifer W hitfield asserts, the Burns Supper plays a crucial role in "bringing the Scottish culture [and] heritage...to the forefront for the St. John's community" and the province as a whole (2007; cf. M owbray 2007c; Reid 2007). Similarly, questionnaire respondents comment on the opportunity the event offers to educate others about Scottish history, to increase local awareness of Scottish culture, and to emphasise "the contribution Scots have made in many fields." It is also regarded as a chance for "non Scots... to have [an] ... involvement in things Scottish."

$M y$ focus in this article is on two performances by local poets Christopher and M ichael Pickard, invited speakers at the January 2007 event, whose contributions encode markedly different attitudes towards tradition and ethnicity to those which underpin the celebration of the Burns Supper as a whole. ${ }^{5} \mathrm{~A}$ nalysis of the Pickard brothers' performances thus affords a valuable opportunity to investigate the tensions which result when competing perspectives confront each other in the context of an organised public event like the Burns Supper. I show how the brothers purposely set out to challenge the implicit norms governing displays of communicative competence at the event, arguing that their contributions represent what José Limón refers to as "temporary ideological breaks" (1983: 202) in its otherwise relatively smooth rhetorical surface. Like the performers of the Mexican-A merican Vanishing $\mathrm{H}$ itchhiker legend variants analysed by Limón, the brothers effectively "'took over' the event and set out their own presence and expressive agenda" for the duration of their performances (1983: 202), setting into motion tensions between their own conceptualisations of tradition and ethnicity and those of most other participants in the Burns Supper. Their contributions can thus be interpreted as an instance of what Limón refers to as metafolkloric performance, in which "a full

after Canadian (47.6\%), English (43.0\%) and Irish $(29.9 \%)$. It was followed by French at $4.2 \%$. The equivalent figures for the province of $\mathrm{N}$ ewfoundland and Labrador as a whole were Canadian 53.4\%; English $39.4 \%$; I rish $19.7 \%$; Scottish $6.0 \%$; and French $5.5 \%$, out of a total of 508,075 single and multiple responses (see Statistics C anada 2002). For wider discussions of the Scottish heritage in N ewfoundland, see O mmer 1980 and Bennett 1989.

5. In addition to pursuing full-time professional careers in other fields, in the past few years the Pickard brothers have gained a degree of local notoriety as poets and entertainers, thanks in large part to a stint as poets laureate for C BC Radio (a position filled through a public contest) and as hosts of a weekly talk show, Speakeasy, on local Rogers cable TV. Christopher has also served as the town crier for the City of St. John's for the past sixteen years (Pickard and Pickard 2007c, 2006). 
display of artistic competence comments upon another" - in this case, the Burns Supper itself as a performance event - by means of "the central performer's ability to exploit event, role and genre" (1983: 205, 202). In closing, I reflect on some possible implications of the organisers' increasing emphasis on entertainment, as exemplified by their decision to invite the Pickard brothers to perform at the 2007 event, for the future direction of the Burns Supper tradition in St. John's.

\section{"Bucking Tradition": the Address to the Haggis}

The brothers' first contribution to the 2007 Burns Supper was the recitation of Burns's poem "To a H aggis." A s M ary Ellen Cohane notes, this recitation has been "at the heart of the celebration" of the Burns Supper since its earliest days and has come to be surrounded by "a larger ritual" in which the haggis is "carried in by a cook in full [cook's] regalia, preceded by a piper" and "addressed" with the words of Burns's poem (1985: 25; see Figures 1-3). ${ }^{6}$ In the brothers' performance, Christopher recites the poem, prefacing his recitation with some introductory remarks about the dish. During this introduction, the performance departs significantly from its usual form - a single speaker - as he is interrupted in mid-sentence by a "protestor," played by $M$ ichael, acting on the mistaken belief that the haggis about to be eaten by the assembled company is an animal which must be rescued from this "barbarous" fate. He storms into the hall carrying a handwritten placard reading "Save the Cuddly Haggis" and featuring a depiction of a small four-legged creature (see Figure 4). Introducing himself as a representative of "PETCA, People for the Ethical Treatment of C uddly A nimals," he declares his intention to "protect this cuddly, beautiful $\mathrm{H}$ ighland haggis, that has been taken from its home for so many years," later accusing two members of the audience of owning "clandestine haggis farms."7 A fter a heated exchange, Christopher succeeds in

6. A ccording to M ary Ellen Brown, the combination of "a shared meal... of haggis, and the recitation of Burns' poem To a Haggis," has formed the "nucleus" of the Burns Supper since the "Proto-celebrations" which took place during the poet's own lifetime, with the poem reputedly having been composed extemporaneously at a dinner he attended sometime in 1785-86 (1984: 119120). For an analysis of To a H aggis and the poem's role in establishing a Scottish "culinary national identity," see Zafar 1996.

7. "PETCA" is a play on PETA, People for the Ethical Treatment of A nimals. A s he goes to leave, the protestor asks if "anybody know[s] where the Canadian 


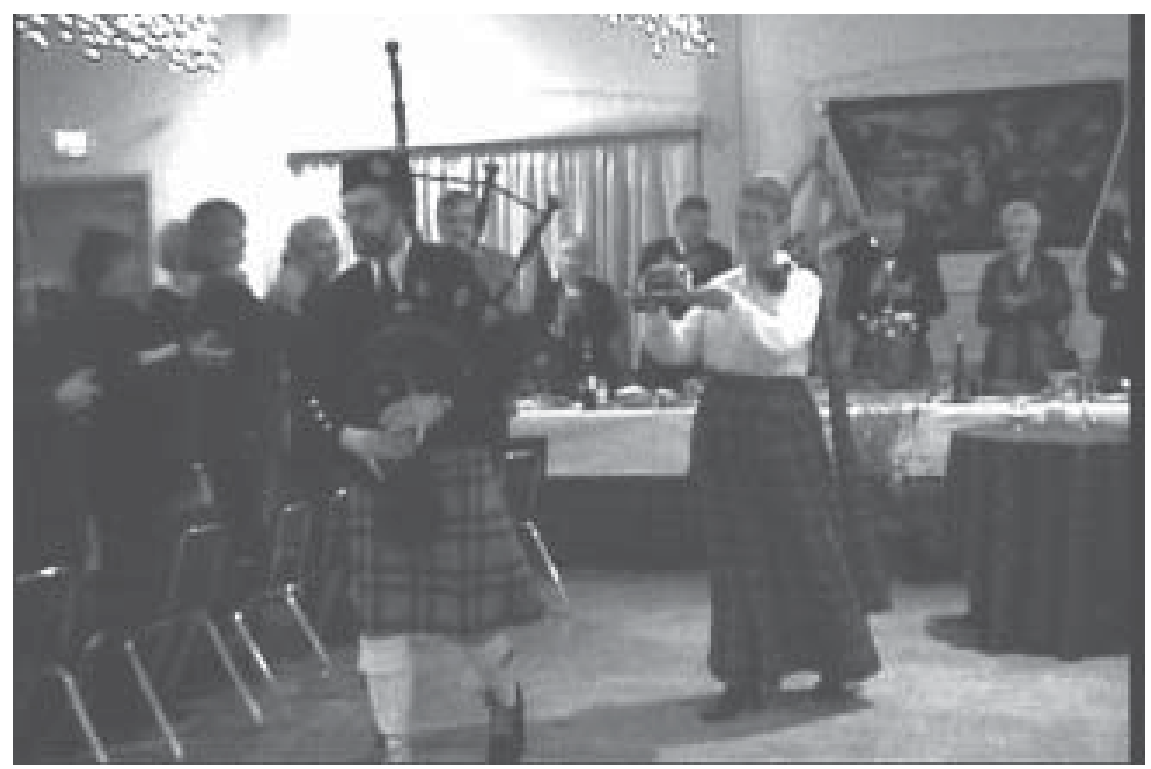

Figure 1. The haggis is piped into the hall at the start of the ceremony and out again at the end.

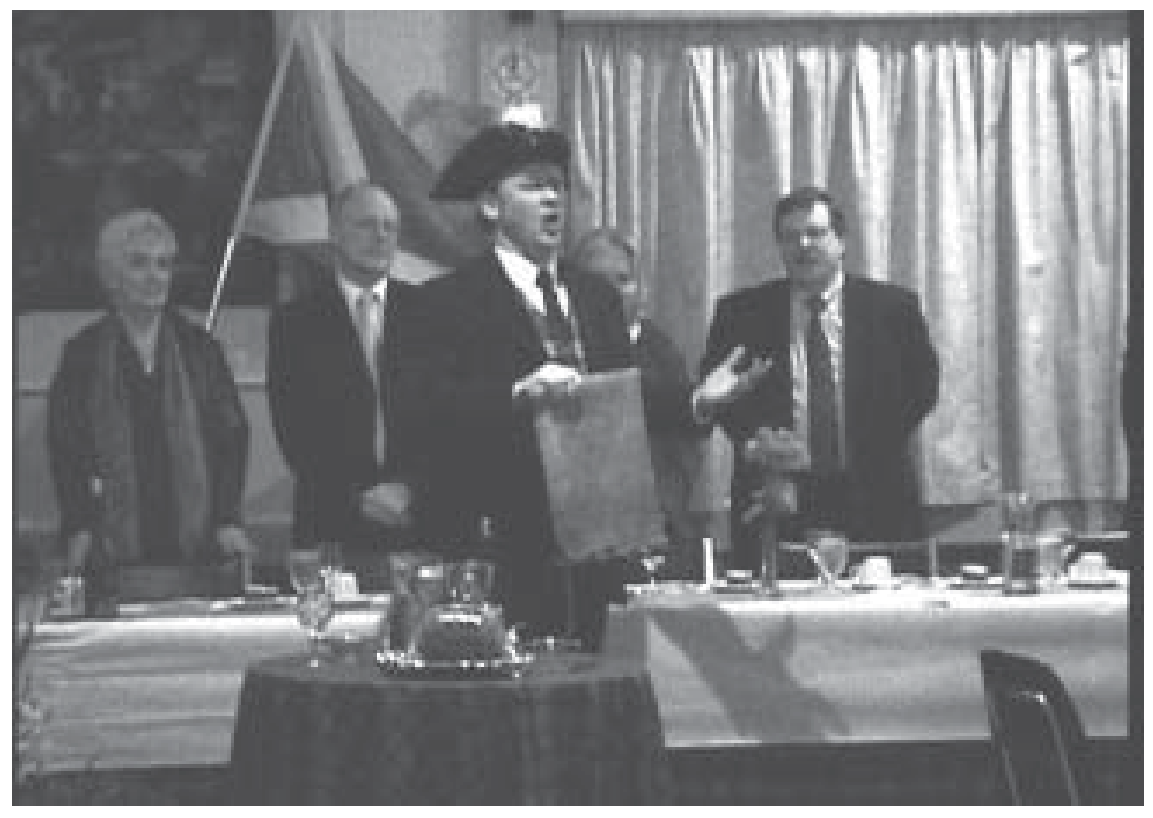

Figure 2. Christopher Pickard "addresses" the haggis with the words of Burns's poem, with the hat and scroll from his role as town crier for the City of St. John's. 
persuading the protestor that the haggis is in fact "not an animal" but "a pudding," and he is invited to stay and join the meal, only to be ejected when it transpires that he is unable to afford the $\$ 40$ ticket price. $^{8}$

A s a narrative centred around an outsider figure who suffers from "confusion" and "misdirection" (Pickard and Pickard 2007c), this performance appears to celebrate the esoteric knowledge of those present by "making a game of the ignorance of outsiders" (Brown 1987: 36). The mock protest is a performed version of the widely known Scottish tall tale which depicts the haggis as a living creature inhabiting the country's mountainsides. However, this performance takes the negative form of a refutation or debunking of the tale, designed to expose the gullibility of one who believes that the creature is real. ${ }^{9}$ In the same way that, as Carolyn Brown writes, the tall tale "delineates an 'in' group and challenges the listener to prove himself clever or dull... through his response to the tale" (1987: 38), the protestor is challenged and found wanting.

$\mathrm{He}$ also violates norms governing expected behaviour at the Burns Supper. A s C hristopher informs him: "you're... creating a scene here that we don't really need"; "we have a ceremony that's about to take place." A s Pauline Greenhill writes of folk poetry, then, the brothers' performance directs criticism and ridicule towards an outsider figure who lacks the "basic cultural knowledge" of those present and, as a

Sealers A ssociation is," a reference to PETA's active involvement in the campaign against the $\mathrm{C}$ anadian seal hunt, which has a particular relevance to N ewfoundland (see PETA 2007; C anadian Sealers A ssociation 2007).

8. The irony of the fact that an animal rights activist should profess a "love" for "sheep's stomach," as the protestor does at the end of this performance, can be interpreted as part of a well-established tradition among N ewfoundlanders of poking fun at anti-seal-hunt campaigners (see Small 2007).

9. Such negative renditions are common within the haggis legend tradition. For a discussion of the legend as it exists in Scottish folk and popular culture, see Fraser 2003. In an interesting twist to this interpretation, when questioned, the brothers claimed never to have heard of the haggis legend prior to our interview. They stated that although they drew on similar stories about the "wild boloney," which enjoy widespread currency in N ewfoundland, they believed that the idea of "describing the haggis as a cuddly little animal" was their own (Pickard and Pickard 2007c). Thus, as David Cornwell and Sandy H obbs note, a folklore item "can be old and yet still 'created' by an individual who happens not to have access to the particular bit of the cultural tradition" (1991: 202). 


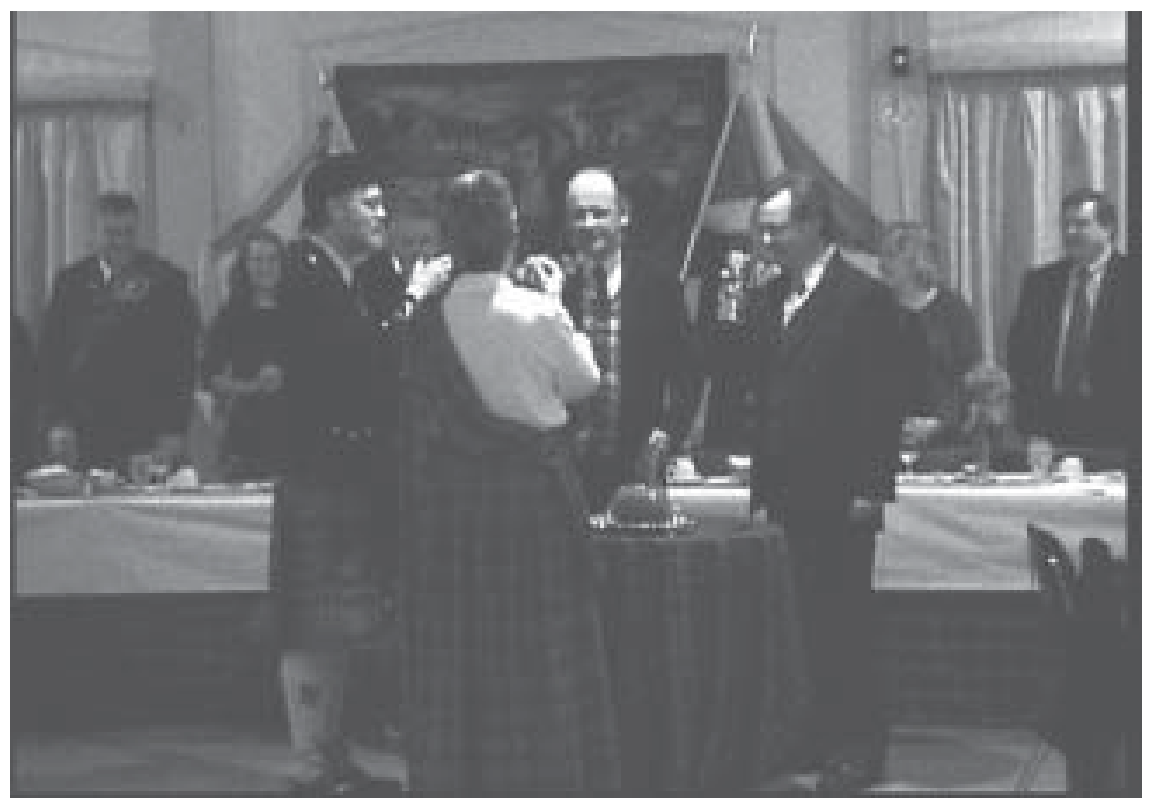

Figure 3. The participants in the ceremony toast the haggis with whisky (L-R: Ean Parsons, piper, Jennifer W hitfield, haggis bearer, Christopher Pickard, M ichael Pickard).

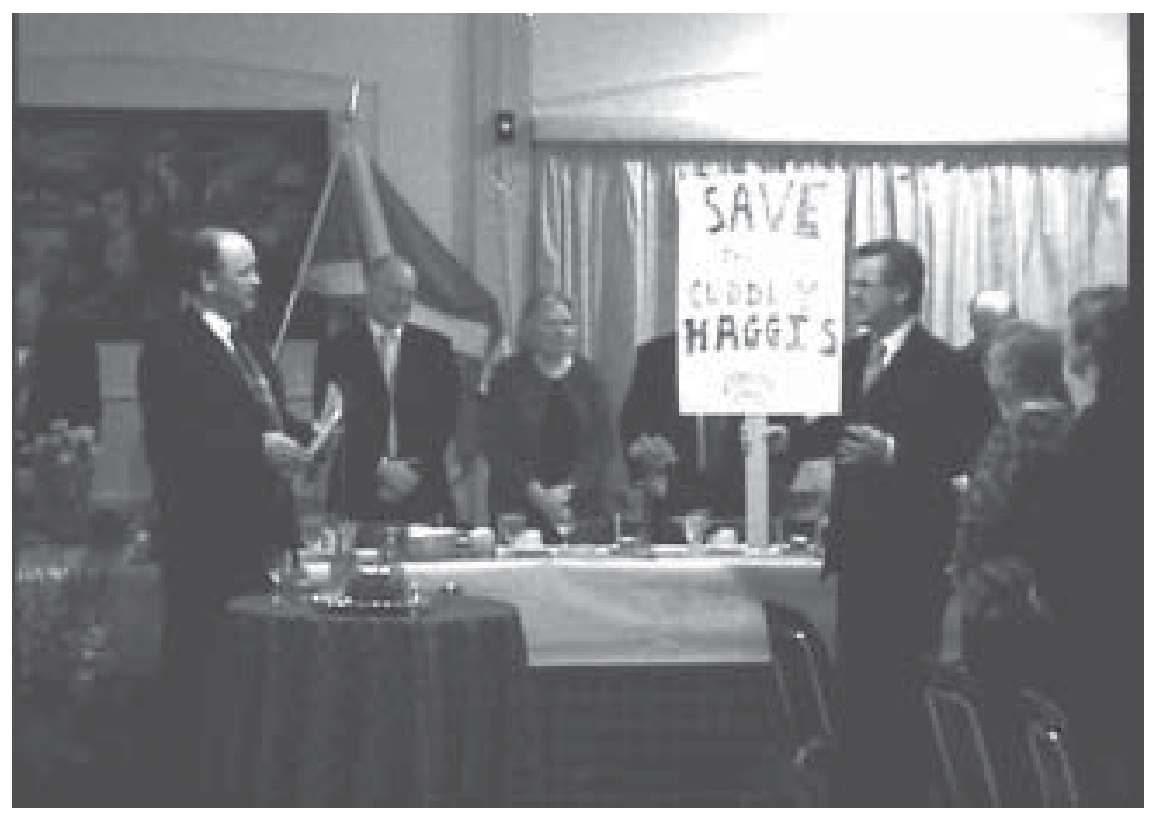

Figure 4. Christopher and the "protestor." 
result, "behaves with humorous inappropriateness" (1989: 82-83). Thus it can be interpreted as a celebration of participants' in-group knowledge of both the haggis itself as a symbol of Scottish ethnicity and its role in the Burns Supper (Cohane 1985: 25-26).

On closer inspection, however, perhaps rather than "approach[ing]... rift and disjunction by attempting to minimize it or to draw the individuals involved together on common appropriate ground," as in the case of the folk poetry analysed by Greenhill (1989: 72), the performance works by purposely emphasising the disjunction created by the protestor's intrusion. This process can be seen especially clearly in the argument between Christopher and the protestor, which centres around the two characters' conflicting attitudes towards tradition. During their exchange, $C$ hristopher informs the protestor that the haggis ceremony is "a time-honoured, traditional event" and the latter responds that "just the very fact that you've been doing this for as long as you've been doing it, does not make it right!"

This argument dramatises the tension between the significance attributed to maintaining tradition by the majority of participants in the Burns Supper, and the playful irreverence towards tradition expressed by the brothers themselves during an interview I conducted with them shortly after the event. A Ithough they state that their respect for the Burns Supper meant that there were aspects of the event that they "didn't want to... mess around with," they emphasise the fact that "we are known to buck... tradition and... do our own thing" (Pickard and Pickard 2007c). They describe how, in planning their contributions, they purposely set out to create "something different" from what they characterise as the "conservative" and non-"performance"-based approach "typically" adopted by other speakers. A s M ichael explains: "I wouldn't say that we're iconoclasts, but we're certainly trying to be a little irreverent sometimes, which is precisely why [we] didn't just... do some kind of speech. We wanted to do something a little different without... being thrown out on our ear" (2007c).

Thus rather than "fit[ting] canons of appropriateness in form [and] content," as Greenhill writes of folk poetry, the brothers' performance purposely pushes the boundaries of folk notions of "situational appropriateness" operating in the context of the Burns Supper ( $G$ reenhill 1989: 158, 107). Just as, at the narrative level, the protestor "reverses or inverts expected, reasonable behaviour" at the Supper, so the brothers 
purposely invert the "expected performative traditions" of the event by framing their contribution explicitly as theatre, thereby creating a parallel disjunction at the level of performance ( $G$ reenhill 1988: 186). ${ }^{10}$

Thus M ichael recalls with pleasure St. A ndrew's Society president G raham M owbray's apparent "concern" with regard to their plans for the event. He states that while "I don't think we scared him per se," "we didn't get the scripts approved or anything like that.... A nd when... we arrived and we had a couple of props, he was looking at me very strangely, saying, 'W hat's that for?'"11 M ichael also comments on the performance's effectiveness in subverting the expectations of the audience, observing that "they thought it was going to be all pomp and circumstance... and then suddenly, this thing happens. W hich was the plan, so that was good" (Pickard and Pickard 2007c). In Richard Bauman's terms, then, the brothers "[use] the structured, conventional performance system" of the Burns Supper "as a base on which a range of communicative transformations can be wrought," employing this system "in a novel, creative... way to fashion a new kind of performance" which manipulates their audience's "conventional expectations and associations" (1975: 301).

The brothers' performance can thus be read as a parody of the haggis ceremony as it is typically performed at the Burns Supper. Peter N arváez defines folk parody as "an artistic form of communication... built upon a pre-existing aesthetic structure," in which "the content or meaning of the initial structure is substantively but not substantially altered" (1977: 33). In the case of humorous folk parody, such forms "imitate to an extent but then exhibit sharp contrasts with original models, the incongruities of which evoke laughter." A ccording to Narváez, humorous folk parodies operate "by maintaining an original structure with the addition of an element of comic surprise which functions as a critical comment on the initial folklore item" (1977: 33) - in this

10. The use of theatrical personae by speakers at the Burns Supper in St. John's is not unprecedented, but it is certainly unusual. O ne other example of which I am aware took place when local actor and comedian Peter Soucy proposed the Toast to the Immortal M emory of Robert Burns in character as Snook, his wellknown "St. John's corner-boy" alter ego (see "Snook" 2006).

11. Introducing the brothers during the event, Graham mentioned that they had been "quite secretive" about what they were planning and that this had caused him "a certain amount of concern" (M owbray 2007b). W hile this came across as a humorous comment, it seems likely that there was some truth behind it. 
case, the haggis ceremony and the wider tradition of the Burns Supper itself. The brothers' decision to frame their performance in this way reflects their own playful tendency towards "bucking tradition," creating a tension in relation to the importance attached to maintaining tradition by most other participants in the event.

\section{Performing Scottishness: the Toast to the Lassies}

The brothers' second contribution to the 2007 Burns Supper was the Toast to the Lassies, one in the series of speeches which comprises the second half of the evening. A s $\mathrm{N}$ ancy $\mathrm{M}$ arshall notes, this is usually "a witty speech about the female sex" which typically incorporates "a few nudges and sly digs about their idiosyncrasies and foibles" (1992: 57). ${ }^{12}$ The brothers' rendition, which bears relatively little resemblance to this description, takes the form of a conversation between $M$ ichael and a Scottish character called Hamish, played by Christopher, who has recently immigrated to St. John's from Fife in Scotland (see Figure 5). The performance concerns the latter's humorously misguided attempts to find a partner in $\mathrm{N}$ ewfoundland. $\mathrm{H}$ amish's misinterpretation of a personal ad in a local newspaper prompts him to compose a poem in response, based on his mistaken assumption that the author of the ad is a "bonny lass" from the Scottish Highlands. A s he recites each verse of his poem, Michael, armed with a copy of the ad, reveals the true meanings of the local references it contains, deriding $\mathrm{H}$ amish for his misinterpretations (see Table 1, columns 1-2).

This time, it is the Burns Supper participants' local knowledge as residents of St. John's which affords them a sense of superiority over $\mathrm{H}$ amish as the ignorant outsider. The audience members' recognition and appreciation of the unwitting double meanings in $\mathrm{H}$ amish's poem, which directly result from his own lack of insider knowledge, appears to put them in a position of authority and control over him (cf. Cornwell and Hobbs 1991: 207). Moreover, taking his imagined romance as a

12. A Ithough M arshall writes that the Toast to the Lassies was "originally... a thank you to the ladies for supplying the food for the evening" (1992: 57), Brown states that it is now typically a "comic or light-veined speech," "often delighting in the recollection of Burns' own way with the 'fair sex,' containing topical and local references, and sometimes illustrating... the versifying and rhyming traditions" which have always been a key feature of the Burns Supper (1984: 130). 
Táble 1: Analysis of Hamish's poem

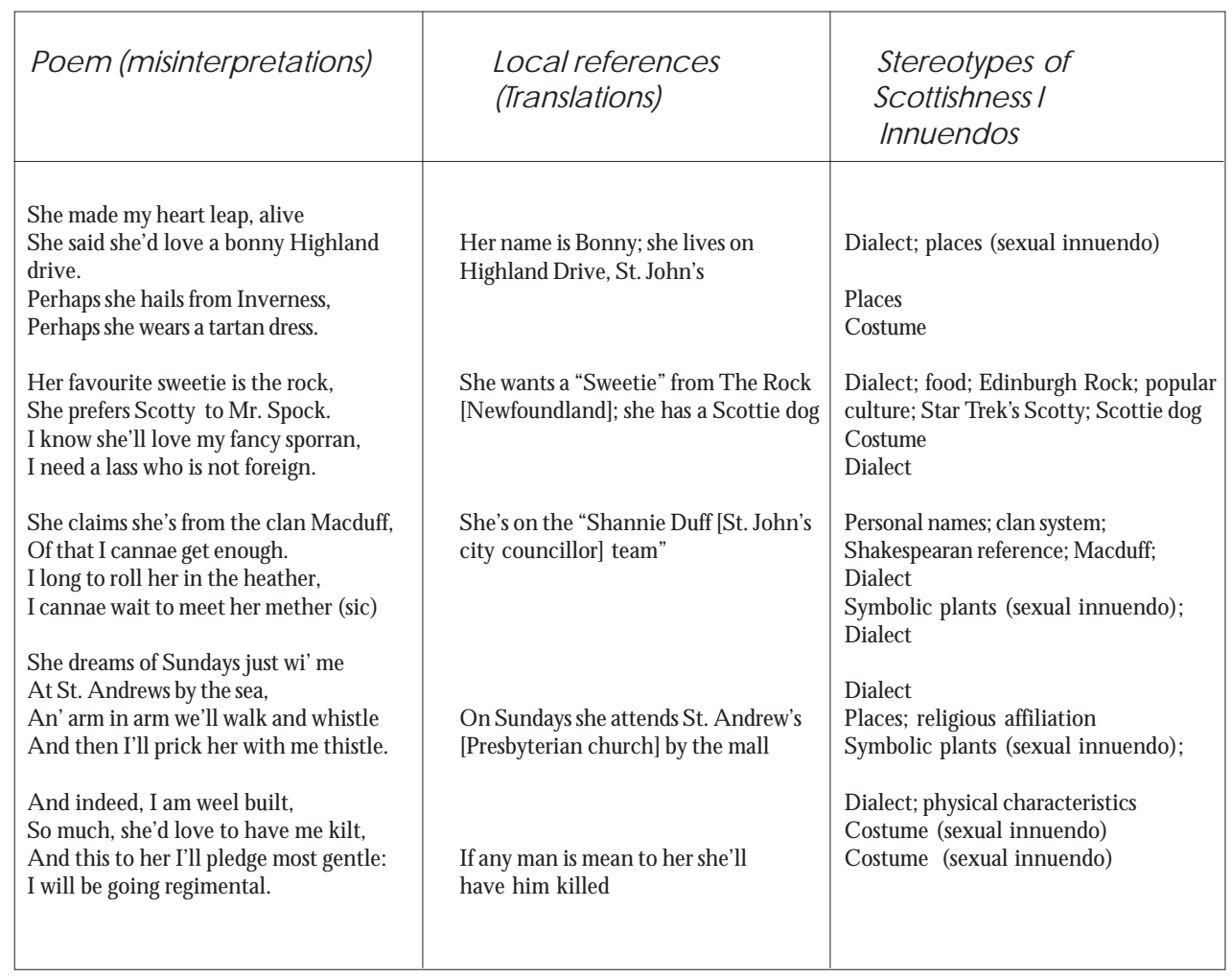

metaphor for Hamish's relationship with his adopted community, we can see that, throughout the performance, he remains excluded from any fulfilling interaction with the in-group. $\mathrm{H}$ is hopes of finding a partner in St. John's are exposed as "all a big dream and fantasy" and he is accused of "imposing your own views of what you want from your homeland country of Scotland" upon the object of his desire, a practice which is characterised as "confused," "deluded" and "pathetic." Those markers of his Scottishness which signal his outsider status are similarly regarded as problematic. He is advised that his accent is "really thick" and that he "should... try to bring it down a few notches" so that "[people will] understand better." $\mathrm{H}$ is "taste for single malt scotch" is identified as a key reason for his lack of success with local women and he is even told that "nobody... likes" his "tartan vest." 
It is noteworthy, in the context of an event whose main purpose is to celebrate Scottish ethnicity, that it is the Scottish character who is represented here as the ignorant outsider. The brothers' overtly sexualised portrayal of $\mathrm{H}$ amish - as seen, for example, in the several instances of sexual innuendo in his poem (see Table 1, column 3) further reinforces his outsider status, reflecting the common tendency to project sexual desire onto the ethnic other (see Lott 1993; M cClary 1992; N eal 1999). ${ }^{13}$ The othering of Scottishness literally enacted by the brothers' performance reflects their ambivalent attitude towards their own ethnic identity as "second-generation Scots," as expressed during our interview. A Ithough their Scottish mother and English father are frequent attendees of the Burns Supper in St. John's, the brothers themselves are relative newcomers to the Burns Supper tradition, the 2007 event being only the second occasion on which they had been present.

Despite stating that they perceive the Supper as "part of our culture," and expressing a desire for it to become "part of our routine culture" (emphasis added), they admit that other priorities have always tended to take precedence over their attendance at the event. A s Christopher comments: "of course, life catches up with you, and then you hear a week before, 'O h, the Burns Supper's coming,' and you just don't have time for that" (Pickard and Pickard 2007c). Their position thus seems to be similar to that of the M exican-A merican tellers of the intercultural jests studied by A mérico Parédes, whose performances "express [their] cultural ambivalence towards their ethnicity" (Limón 1983: 193; see Parédes 1968: 113-114). This attitude contrasts markedly with the significance attributed to ethnicity by most other participants in the Burns Supper. ${ }^{14}$

The resulting tension is heightened by the fact that the brothers' performance of Scottishness works in large part by satirising precisely those conceptualisations of Scottish ethnicity which underpin the

13. In contrast, the $\mathrm{N}$ ewfoundlander who features in the performance is depicted, unusually, as relatively prudish and strait-laced, disapprovingly referring to $\mathrm{H}$ amish as "a dirty bird."

14. N onetheless, the audience appears to have uncritically accepted the brothers' portrayal of the Scot as other, probably reflecting the fact that the majority of participants in the Burns Supper enjoy only indirect links, if any, to Scotland. of a total of thirteen respondents to the audience questionnaire, only two were born in Scotland. O ne is married to a Scot, and two others have "distant family connections." The remainder has no apparent connection to Scotland other 


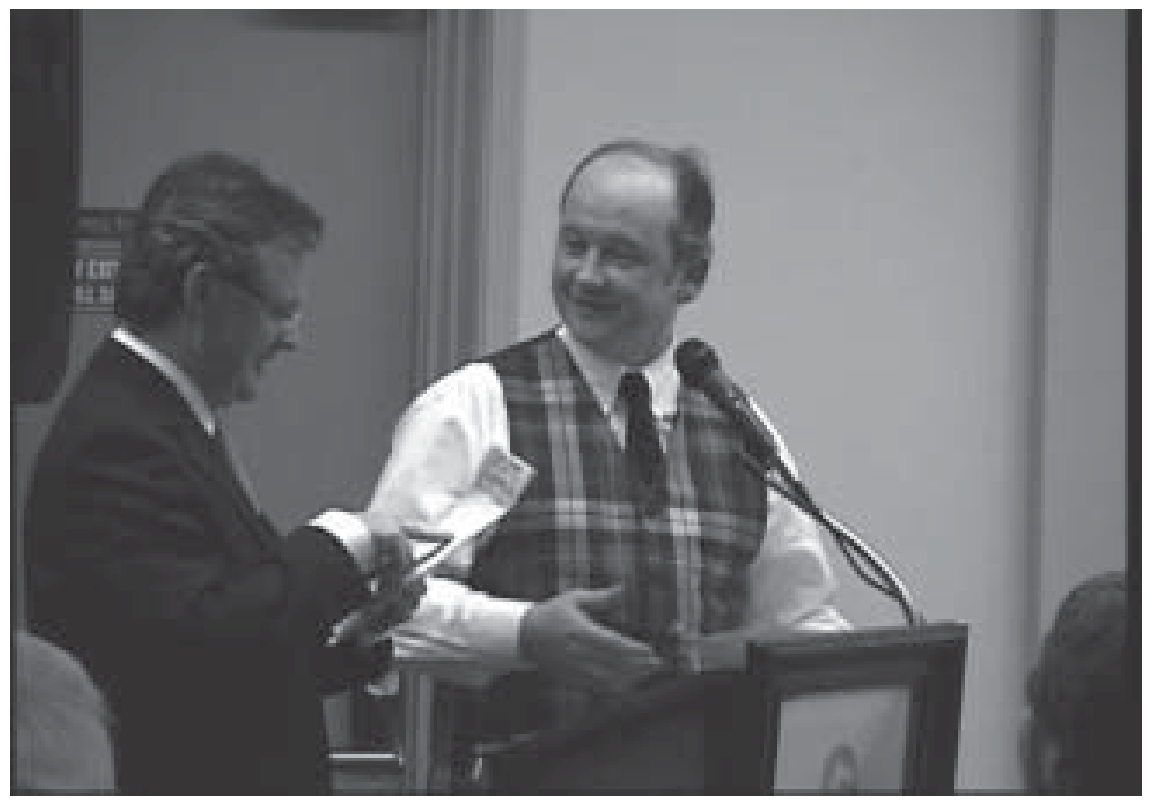

Figure 5. Michael and "Hamish."

celebration of the Burns Supper in St. John's itself. Firstly, it satirises the tendency among the diaspora to create selective and romanticised constructions of the homeland. A gain taking Hamish's imagined romance as a metaphor for ethnicity, this time for his relationship with his homeland, we can see that the remembered Scotland represented by his ideal woman is an incongruous combination of a Highland idyll of heather-covered mountains, populated by "bonny lasses" in "tartan dresses" still living under the clan system, and of the blissful Sunday afternoons he imagines, later in his poem, spent strolling al ong the beach at St. A ndrews in his native Fife (see Table 1, column 1). In other

than friendships with Scots and membership of interest groups such as the local branch of the Royal Scottish Country Dance Society and the local Scottish Country Dance Band, Corryvreckan, both of which perform at the Supper. Thus, as A ndriy $N$ ahachewsky writes of ethnic identification among later generational U krainian Canadians, the Burns Supper participants' Scottish ethnicity "is to a large extent a voluntary, situational, and part-time identity" (2002: 176).T heir position exemplifies the concept of new ethnicity, which $\mathrm{N}$ ahachewsky uses to refer to "persons and groups who consciously choose to claim this ethnicity and both privately and publicly incorporate ethnically defined cultural practices" (2002: 177). 
words, as one audience member puts it, it is "a celebration of a few things that may be associated with Scotland... but if anything it is a Romantic ideal of Scottishness with... only a limited connection to the realities of modern Scotland." Significantly, however, this audience member refers not to Hamish's idealised memories of his homeland but to the representation of Scottishness encoded in the Burns Supper as it exists in present-day St. John's. H er observation thus neatly demonstrates how Hamish's practice of "imposing your own views of what you want from your homeland" can equally be applied to the selective usage of contested icons of Scottishness in the context of the Burns Supper itself.

The brothers' portrayal of $\mathrm{H}$ amish himself reinforces this argument. $\mathrm{H}$ is use of Scottish dialect and penchant for "versifying" (Brown 1984: 130), his "tartan vest" and allusions to his kilt and "fancy sporran," and his taste for those other iconic Scottish foodstuffs, the deep-fried M ars Bar and Edinburgh rock (hard candy), are all humorously exaggerated versions of the three key signifiers of Scottishness encoded in the Burns Supper: language, costume and foodways (e.g., see Table 1, column 3). ${ }^{15} \mathrm{Q}$ uestionnaire responses indicate that in the context of the Supper, signifiers such as "bagpipes, dancers, haggis, accents [and] kilts" are largely accepted unproblematically as authentic representations of Scottishness, a fact which can be attributed to a process that Wayne Fife terms semantic slippage. A ccording to Fife, semantic slippage enables "time and/or space to collapse" so that "what is taken to be the 'original' meaning of an object" or concept - in this case, the meaning

15. O ther stereotypes of Scottishness featured in this performance are drawn from popular culture and literature (Scotty from Star Trek; Shakespeare's M acduff); and from perceptions concerning Scots' anti-Englishness (Hamish mentions Captain Picard's "cheap English measures," apparently confusing the Star Trek character's French nationality with that of Patrick Stewart, the English actor who portrays him - and also playing on the brothers' own surname); Scottish flora and fauna (heather, thistles, Scottie dogs); social organisation (the reference to the clan system); and religious affiliation (Presbyterianism) (see Table 1, column 3). When asked how they came up with the ideas about Scottishness included in their speech, Christopher describes how "we just brainstormed from our own experience, growing up with a Scottish mother and having both made a couple of trips over that way. A ny references we could think of we wrote them down first, that had anything to do with Scotland. A nd...we had a list of maybe about thirty things, that ranged from Loch N ess M onsters to Edinburgh rock. A nd then we tried to fit what we could in" (Pickard and Pickard 2007c). 
of Scottishness itself - "collapses into the contemporary meaning of an object or enactment," thereby justifying the latter's authenticity (2004: 63-64).

In H amish's case, in contrast, these same signifiers are exaggerated to the point of ridiculousness, signalling that the brothers' caricature of Scottishness is not to be taken "too seriously" by rendering the process of semantic slippage "too obviously and visibly 'wrong'" (Fife 2004: 64; cf. Cohane 1985: 27). Fife identifies objects or enactments that operate in this way as postmodern forms which are "not... about the modernist project of authenticity but rather about poking fun at the idea that such 'authenticity' is possible" (2004: 65). A similar case can be made about the attitude towards Scottish ethnicity encoded in the brothers' performance.

This interpretation accords with a revealing exchange which took place during our interview, when Christopher expresses his desire to own a kilt which he could wear to attend future Burns Suppers, but adds that "I'm looking at other expenses that I think are probably bigger priorities right now." At this point, Michael interrupts him to suggest that he should sell his "burqa," his "kimono" and his "Peruvian poncho" that he keeps in his "tickle trunk" in order to raise enough money to buy himself a kilt (Pickard and Pickard 2007c). This exchange encapsulates the distinctly postmodern conceptualisation of ethnicities as playful "costumes" that can be dressed up in and changed out of at will, which clearly manifests itself in the brothers' playfully stereotypical performance of Scottishness in the Toast to the Lassies. Such a conceptualisation sits uneasily, however, alongside the significance accorded to ethnicity by most other participants in the Burns Supper, and their acceptance of the contested symbols it incorporates as authentic representations of Scottish identity.

\section{Tradition, Ethnicity and the Newfoundland St. Andrew's Society Bums Supper}

$M y$ analysis has shown how focusing on two performances in which unspoken communicative rules are broken can help to illuminate wider issues relating to tradition and ethnicity at play within the discourse of the Newfoundland St. Andrew's Society Burns Supper. Both performances appear to celebrate the esoteric knowledge of those present - in their dual status as Burns Supper attendees and 
N ewfoundlanders - by "making a game of the ignorance of outsiders" (Brown 1987: 36). A closer reading, however, reveals how they set into motion tensions between the conceptualisations of tradition and ethnicity held by the event's organisers and participants, and those of the Pickard brothers themselves.

The St. A ndrew's Society's decision to invite "two young comedians," as one committee member describes them, to speak at its 2007 event reflects a gradual process of "informalisation" undergone by the Burns Supper in St. John's in recent years (W hitfield 2007; M owbray 2007c). In fact, this process was adopted as an unofficial policy by the event's organising committee around fifteen years ago, partly in an attempt to reverse a declining trend in attendance figures. A s president $\mathrm{G}$ raham $M$ owbray recalls, the committee found itself urgently faced with the issue of "how [to]... maintain all that tradition, all the good stuff," while at the same time introducing changes that would help to "bring in new people, younger people" and thereby "drive the ticket sales up" (2007c). Thus, although many participants continue to wear kilts and other tartan dress, the Supper is no longer advertised as a black tie event. The number of speeches and toasts featured as part of the event has been decreased, together with the permitted length of the speeches themselves, and the choice of speakers is no longer made exclusively from the upper stratum of local society. Changes such as these are mirrored in the evolution of many other Burns Suppers both in Scotland and elsewhere.

Such developments reflect an increasing emphasis on entertainment which is encapsulated in G raham's description of the present-day Burns Supper in St. John's. A s he states:

It's the equivalent of dinner theatre.... A nd although there's a tremen dous history which we can talk about... now, for us to get people coming, and therefore for us to keep the tradition alive, we have to entertain them, we have to keep them moving along. You can't have them there ... at twelve-thirty at night, with someone continuing just to give you another detail in Robert Burns's life (M owbray 2007c).

This observation indicates a significant shift in the conceptualisation of tradition on the part of the event's organisers, towards a view in which traditions must adapt to survive, and in which "carrying on the tradition" becomes the justification for increasing informalisation and popularisation. This new emphasis on entertainment suggests that performances such as the Pickard brothers' may well become more of the norm in future years, perhaps effecting a lasting shift in the "structured, 
conventional performance system" itself (Bauman 1975: 301). The implications of such a development for the public celebration of ethnicity among diaspora communities like the Scots in St. John's are well deserving of further study.

A s A ndriy $\mathrm{N}$ ahachewsky writes, conceiving of ethnicity as "a constructed part of reality, a learned aspect of identity and behavior at least as much as an inherited one," enables scholars to explore how "perceived ethnic boundaries remain critically relevant for the existence of specific ethnic groups, while the objective cultural content can and does change" (2002: 175). A nalysis of the evolving Burns Supper tradition in St. John's illustrates how participants' conceptualisations of tradition and ethnicity have adapted to accommodate changing cultural circumstances and tastes, as reflected, for example, in the adoption of an increasingly entertainment-centred, theatrical performance mode. However, such processes of change do not always proceed uncontested, but may be characterised by tensions between competing perspectives, values and aesthetics. A s this study has shown, focusing on these tensions and their expression within the discourse of an event like the Burns Supper in St. John's can offer key insights into the complex meanings of tradition and ethnicity among groups such as the N ewfoundland St. A ndrew's Society. 


\section{References}

Bauman, Richard. 1975. "Verbal A rt as Performance." A merican A nthropologist 77: 290-311.

Bennett, M argaret. 1989. The Last Stronghold: Scottish $G$ aelic Traditions in N ewfoundland. St. John's, N L: Breakwater.

Brown, Carolyn S. 1987. T he Tall Tale in A merican Folklore and Literature.

Knoxville: U niversity of Tennessee Press.

Brown, M ary Ellen. 1984. Burns and Tradition. London: M acmillan.

Canadian Sealers Association. 2007. Homepage. http:// www. sealharvest.ca

Cohane, M ary Ellen. 1985. "H aggis as Trope: Scottish-A merican Foodways in N ew Jersey." N ew Jersey Folklore 10: 24-29.

Cornwell, David, and Sandy H obbs. 1991. "D efining the Pun." In G illian

Bennett ed., Spoken in Jest: 199-214. Sheffield: Sheffield A cademic Press.

Crawford, Robert, ed. 1997. Robert Burns and Cultural A uthority. Edinburgh: Edinburgh U niversity Press.

Davis, Leith. 1998. "Re-presenting Scotia: Robert Burns and the Imagined Community of Scotland." In Carol McGuirk ed., C ritical Essays on Robert Burns: 63-76. N ew York: Hall.

Fife, W ayne. 2004. "Semantic Slippage as a N ew A spect of A uthenticity:

Viking Tourism on the N orthern Peninsula of N ewfoundland." Journal of Folklore Research 41: 61-84.

Finlay, Richard J. 1997a. "The Burns Cult and Scottish Identity in the $N$ ineteenth and Twentieth Centuries." In Kenneth Simpson ed., Love and Liberty: Robert Burns: A Bicentenary Celebration: 69-78. East Linton (UK): Tuckwell Press.

- - - . 1997b. "H eroes, M yths and A nniversaries in M odern Scotland." Scottish A ffairs 18: 108-125.

Fraser, Joy. 2003. "'G ie her a Haggis!': Haggis as Food, Legend and Popular Culture." C ontemporary Legend n.s. 6: 1-43.

Greenhill, Pauline. 1988. "Folk Drama in A nglo C anada and the M ock

W edding: Transaction, Performance, and M eaning." $C$ anadian

D rama/L'A rt dramatique canadien 14: 169-205.

--- . 1989. True Poetry: Traditional and Popular Verse in 0 ntario.

M ontreal and Kingston: M cG ill-Q ueen's U niversity Press.

Hammond, Brean. 1993. "'O ur toils obscure, and a' that': Burns and the Burns M yth." In Hans U Irich Seeber and Walter Göbel eds., A nglistentag 1992 Stuttgart: Proceedings: 9-19. Tübingen: N iemeyer. Kirkwood, Colin. 2000. "Robert Burns in the Counsellor's C hair: A Socio-Cultural Analysis of the Burns Myth." Psychodynamic 
Counselling 6: 521-531.

Limón, José E. 1983. "Legendry, M etafolklore, and Performance: A

M exican-A merican Example." W estern Folklore 42: 191-208.

Lott, Eric. 1993. Love and Theft: Blackface M instrelsy and the A merican

Working Class. Oxford: Oxford U niversity Press.

Marshall, Nancy. 1992. C hambers Companion to the Burns Supper.

Edinburgh: Chambers.

M cClary, Susan. 1992. G eorge Bizet's C armen. Cambridge: Cambridge U niversity Press.

M cG uirk, Carol. 1987. "Scottish H ero, Scottish Victim: M yths of R obert

Burns." In Cairns Craig gen. ed., The $\mathrm{H}$ istory of Scottish Literature,

Vol. II: 219-238. A berdeen: A berdeen University Press.

- - - 1997. "H aunted by A uthority: $N$ ineteenth-C entury A merican

Constructions of Robert Burns and Scotland." In Robert Crawford

ed., Robert Burns and Cultural A uthority: 136-158. Edinburgh:

Edinburgh U niversity Press.

M owbray, G raham. 2002. "The N ewfoundland St. A ndrew's Society."

In N oreen M acLennan ed., "A II A round the C ircle": Scottish C ountry

Dances from N ewfoundland, Volume 1: 6. St. John's, N L: St. John's

(N ewfoundland) Branch, Royal Scottish Country Dance Society.

- - - . 2007a. Introduction to "The Immortal M emory of Robert

Burns." Speech presented at N ewfoundland St. A ndrew's Society

Burns Supper, 20 January. Tape recording.

- - - . 2007b. Introduction to "The Toast to the Lassies." Speech

presented at Newfoundland St. A ndrew's Society Burns Supper, 20

January. Tape recording.

- - - . 2007c. Interview with the author, 22 February, St. John's. Tape

recording.

Nahachewsky, A ndriy. 2002. "N ew Ethnicity and U krainian Canadian

Social Dances." Journal of A merican Folklore 115: 175-190.

N eal, Sarah. 1999. "Populist Configurations of Race and Gender: The

C ase of $\mathrm{H}$ ugh $\mathrm{G}$ rant, Divine Brown and Elizabeth H urley." In A vtar

Brah, $\mathrm{M}$ ary J. Hickman, and $\mathrm{M}$ aírtín $\mathrm{M}$ ac an Ghaill eds., Thinking Identities: Ethnicity, Racism and Culture: 100-119. London: M acmillan.

N ewfoundland St. A ndrew's Society. 2007. Homepage: http:// www3.nf.sympatico.cathe.mowbrays/starter.html

O mmer, Rosemary E. 1980. T he Scots in N ewfoundland. Paper presented to the N ewfoundland Historical Society, St. John's.

Parédes, A mérico. 1968. "Folk M edicine and the Intercultural Jest." In June Helm ed., Spanish-Speaking People in the U nited States: 104119. Seattle: U niversity of W ashington Press. 
PETA. 2007. "Stop Barbaric Seal Slaughter." http:// www. hel pinganimal s.com/automation2/A lertl tem.asp?id=698

Pickard, Christopher, and M ichael Pickard. 2006. "Speakeasy Central." http://rogersspeakeasy. blogspot.co

- - - . 2007a. "A ddress to the Haggis." Performance presented at N ewfoundland St. A ndrew's Society Burns Supper, 20 January. Video recording.

- - . 2007b. "Toast to the Lassies." Performance presented at N ewfoundland St. A ndrew's Society Burns Supper, 20 January. Video recording.

- - - . 2007c. Interview with the author, 27 February, St. John's. Tape recording.

Reid, Ross. 2007. "Toast to Scotland." Speech presented at N ewfoundland St. A ndrew's Society Burns Supper, 20 January. Tape recording.

Roe, Nicholas. 1997. "A uthenticating Robert Burns." In Robert

Crawford ed., Robert Burns and Cultural A uthority: 159-179. Edinburgh: Edinburgh U niversity Press.

Small, C ontessa. 2007. "A musement as A mmunition: Jokes and Parodies of the 2006 Newfoundland Seal H unt Protest." C ulture \& Tradition 29: $137-155$.

"Snook." 2006. Homepage. http://www.rightonsnook.com

Statistics C anada. 2002. "Ethnocultural Portrait of Canada: Highlight

Tables, 2001 Census." http://www12.statcan.ca/english/census01/ products/highlight/Ethnicity/ Index.cfm?Lang=E

Strauss, Dietrich. 1989. "Burns - Literary Focus of Scottish National Identity?" In Horst W. Drescher and Hermann Völkel eds., $\mathrm{N}$ ationalism in Literature/Literarischer $\mathrm{N}$ ationalismus: Literature, Language and $\mathrm{N}$ ational Identity: T hird International Scottish Studies Symposium: Proceedings: 107-116. Frankfurt am Main: Lang.

Trew, Johanne Devlin. 2005. "The Forgotten Irish?: Contested Sites and Narratives of N ation in N ewfoundland." Ethnologies 27(2): 4377.

Tyrrell, A lex. 2005. "Paternalism, Public M emory and N ational Identity in Early Victorian Scotland: The Robert Burns Festival at Ayr in 1844." H istory 90: 42-61.

W hitfield, Jennifer. 2007. Interview with the author, $20 \mathrm{M}$ arch, St. John's. Tape recording.

Zafar, Rafia. 1996. "The Proof of the Pudding: O f H aggis, H asty Pudding, and Transatlantic Influence." Early A merican Literature 31: 133-149. 